\title{
Evaluation of Low Phosphorus Tolerance of Rice Varieties in Northern Ghana
}

\author{
Williams Kwame Atakora ${ }^{1}$, Mathias Fosu ${ }^{1}$, S. O. Abebrese ${ }^{1}$, Michael Asante ${ }^{1} \&$ Matthias Wissuwa $^{2}$ \\ ${ }^{1}$ CSIR-Savanna Agricultural Research Institute, Post Office Box TL 52, Tamale, Ghana \\ 2 Japan International Research Center for Agricultural Sciences (JIRCAS), 1-1 Ohwashi, Tsukuba, Ibaraki, \\ 305-8686 Japan
}

Correspondence: Williams Kwame Atakora, CSIR-Savanna Agricultural Research Institute, Post Office Box TL 52, Tamale, Ghana. E-mail: williatnet@gmail.com

Received: October 30, 2014 Accepted: December 11, $2014 \quad$ Online Published: September 22, 2015

doi:10.5539/sar.v4n4p109 URL: http://dx.doi.org/10.5539/sar.v4n4p109

\begin{abstract}
Phosphorus (P) deficiency is a major constraint to upland rice production on highly weathered, low activity clay soils in the humid zones of West Africa. There is a paucity of information on the short-term fertilizer P effects on rice on these soils. A field experiment was conducted in 2011 to determine the response of twenty-four (24) upland rice cultivars to fertilizer Phosphorus (P) applied at 0 and $60 \mathrm{~kg} \mathrm{P} \mathrm{ha}^{-1}$. An uncultivated field at SARI research area with available $\mathrm{P}$ (Bray 1) P content of $3.0 \mathrm{mg} / \mathrm{kg}$ was used for the experiment.

The ploughed area was divided into two plots with one plot for $+\mathrm{P}$ and the other for $-\mathrm{P}$ treatment. Each of the 24 varieties was allocated three rows and spaced at $20 \times 10 \mathrm{~cm}$ in four replications. The varieties were randomized for each replicate and planted on $2^{\text {nd }}$ July 2011 at one seed per hill. Pre-emergence herbicide Pendimethaline 400 g/l (Alligator) was applied at $3.2 \mathrm{~L} /$ ha two days after planting followed by one hand weeding. For the (-) P plot, the entire field received $\mathrm{N}$ at $60 \mathrm{~kg} / \mathrm{ha}$ as Sulphate of ammonia and $\mathrm{K}_{2} \mathrm{O}$ at $60 \mathrm{~kg} / \mathrm{ha}$ as Muriate of Potash. For the (+) P plot, fertilizer was applied at NPK 60-60-60 kg/ha from Sulphate of ammonia, Triple superphosphate and Muriate of potash, respectively. For each plot, the $\mathrm{N}$ was split applied.

Results showed that the plants that received $\mathrm{P}$ were more vigorous and healthier. There was significant variety effect on number of tillers per plant (NOTPP), days to $50 \%$ flowering (DFF), days to maturity (DTM), dry weight of biomass (DWOB), number of panicles per plant (NOPPP), and grain yield per plant. Similarly, there was significant phosphorus effect on number of tillers per plant (NOTPP), days to 50\% flowering (DFF), days to maturity (DTM), dry weight of biomass (DWOB), number of panicles per plant (NOPPP), and grain yield per plant. There was generally no interactive effect of variety by fertilizer except for DFF and DTM. The number of tillers per plant ranges from 3 - 16 with the overall mean without $\mathrm{P}$ application being 4 while overall mean with $\mathrm{P}$ application was 9 . When $\mathrm{P}$ was applied, the number of days to $50 \%$ flowering reduced from 86 days to 79 days. Days to maturity (DTM) was also reduced from 118 to 111 on average by P application. The varieties that were most tolerant to low P were ITA 257, Nerica 3 and TOX 1011-4-A2. The grain yield of ITA 257 remained the same whether P was applied or not. This is the variety that is best adapted to low P. We concluded that rice growth and yield components were affected by Phosphorus application. Plants that received phosphorus flowered and matured earlier. They also accumulated higher biomass and grain yield. ITA 257, Nerica 3 and TOX 1011-4-A2 were most tolerant to P deficiency.
\end{abstract}

Keywords: drought, tolerance, deficiency, varieties, tillering and panicles

\section{Introduction}

Phosphorus is one of the major nutrient elements out of 16 essential elements required in rice nutrition. Its beneficial effects on plant growth are stimulation of root development, early flowering, and ripening and promotion of good grain development, and quality (Datta, 1965, 1981). Phosphorus deficiency in soils is an important nutritional problem in tropical soils.

However, all the soils in the tropics are not $\mathrm{P}$ deficient and those that are deficient do not always require large amounts of P fertilizers (Fox \& Searley, 1978). In deficient soils application of large amounts of phosphatic fertilizer may pose financial problems to the farmers. An alternative method to overcome the P. deficiency .in 
wetland rice soils is to breed varieties tolerant to P deficiency even though it may not be effective under extreme conditions. Tadano and Tanaka (1980) concluded that rice compared to other plant species has a strong tolerance to low phosphate conditions. They also indicated that differences in tolerance to low phosphate conditions were controlled (1) mainly by tolerance to low P content in the plant, (2) phosphorus absorbing power per unit root weight and (3) distribution of absorbed phosphorus between root and' shoot.

Phosphorus $(\mathrm{P})$ is one of the most important but also most limiting plant nutrients, especially in Africa where an estimated $50 \%$ of cropland suffers some degree of $\mathrm{P}$ deficiency. On these soils, upland rice is often cultivated without or only with little fertilizer input by smallholder farmers that depend on the crop for food security and their livelihoods. For these farmers varieties are required that thrive on little available indigenous soil $\mathrm{P}$ especially during early growth stages to better compete with weeds, the main constraint apart from low soil fertility. As a first step towards developing cultivars with higher P efficiency, a screening experiment was conducted to identify the level of tolerance to $\mathrm{P}$ deficiency in 24 rice cultivars that are widely grown in the African uplands in a collaborative research with JIRCAS under the project "Development of rice-production technology in Africa". The experiment was conducted at the experimental field of SARI from July to November 2011 to determine the mechanism of varietal tolerance to P deficiency in upland rice.

\section{Materials and Methods}

In order to site the experiment on a P deficient soil, an uncultivated upland field at the SARI research field near the water treatment site was selected. Composite soil samples were taken from $0-20 \mathrm{~cm}$ depth over $0.1 \mathrm{ha}$ area and analyzed for Bray-1 P, which was found to be $3.04 \mathrm{mg} / \mathrm{kg}$. The site was considered appropriate for the experiment. The land was ploughed with disc plough and harrowed with a disc harrow. Thereafter, leveling was done with hand hoe.

The ploughed area was divided into two plots with one plot for $\mathrm{P}$ application and the other without $\mathrm{P}$ application. The separate fields were lined and pegged for the experiment. Each variety was allocated three rows and spaced at $20 \times 10(20) \mathrm{cm}$. The distance between varieties was $30 \mathrm{~cm}$. There were four replications. Planting (Kindly check the spacing).

The varieties were randomized for each replicate and planted on $2^{\text {nd }}$ July at one seed per hill when the soil was moist sufficiently for seed germination. The entire field was fenced to keep away animals. Pre-emergence herbicide Pendimethaline $400 \mathrm{~g} / 1$ (Alligator) was applied at $3.2 \mathrm{~L} / \mathrm{ha} 2$ days after planting. Thereafter weeds were hand-picked once when it became necessary.

For the (-) P plot, the entire field received $\mathrm{N}$ at $60 \mathrm{~kg} / \mathrm{ha}$ as Sulphate of ammonia and $\mathrm{K}_{2} \mathrm{O}$ at $60 \mathrm{~kg} / \mathrm{ha}$ as Muriate of Potash. For the (+)P plot, Fertilizer was applied at NPK 60-60-60 kg/ha from Sulphate of ammonia, Triple superphosphate and Muriate of potash, respectively. For each plot, the $\mathrm{N}$ was split applied. The basal N (30 $\mathrm{kg} / \mathrm{ha}$ ) was applied with all the $\mathrm{P}$ and $\mathrm{K}$ at 14 days after planting. The remaining $\mathrm{N}$ was applied 42 days after planting. Germination count was done 14 days after planting. Other data collected were, plant vigour, Days to 50\% flowering, tiller count/plant for 10 plants, biomass at vegetative and harvest stage and grain yield.

\section{Results}

Germination of the rice seeds was generally low. Germination percentage ranged from 12 to $52 \%$. The Nericas were more vigorous at vegetative stage and maintained fairly high biomass throughout the growth period. Generally, the plants that received $\mathrm{P}$ were more vigorous and healthier. There was significant variety effect on number of plants germinated (NOPG) and germination percent (GP), number of plants established per plot (NOPEPP), number of tillers per plant (NOTPP), days to $50 \%$ flowering (DFF), days to maturity (DTM), dry weight of biomass (DWOB), number of panicles per plant (NOPPP), and grain yield per plant. Similarly, there was significant phosphorus effect on number of tillers per plant (NOTPP), days to $50 \%$ flowering (DFF), days to maturity (DTM), dry weight of biomass (DWOB), number of panicles per plant (NOPPP), and grain yield per plant (Table 1). There was generally no interactive effect of variety by fertilizer except for DFF and DTM (Table $1 \& 2$ ). The number of tillers per plant ranges from $3-16$ with the overall mean without $\mathrm{P}$ application being 4 while overall mean with $\mathrm{P}$ application was 9 (Table 2). When $\mathrm{P}$ was applied, the number of days to $50 \%$ flowering reduced from 86 days to 79 days. Days to maturity (DTM) was also reduced from 118 to 111 on average by $\mathrm{P}$ application. The varieties that were least affected by low P were ITA 257, Nerica 3 and TOX 1011-4-A2 (Table 5). The grain yield of ITA 257 remained the same whether P was applied or not. This is the variety that is best adapted to low P. Moroberecan did not have any grain yield due to abrupt end of the rains in early October. 
Table 1. Mean sums of squares for the various parameters considered

\begin{tabular}{lccccccccccc}
\hline Source & d.f. & NOPG & GP & NOPEPP & NOTPP & DFF & DTM & FWOB & DWOB & NOPPP & GYPP \\
\hline Blocks & 3 & 388.76 & 3077.9 & 530.47 & 42.7 & 2.14 & 0.45 & 22227 & 968.9 & 11.99 & 98 \\
Variety (V) & 23 & $631.01^{* *}$ & $870.4^{* *}$ & $1003.39^{* *}$ & $61.93^{* *}$ & $821.43^{* *}$ & $679.61^{* *}$ & $5277^{* *}$ & $222.6^{*}$ & $41.13^{* *}$ & $43.55^{* *}$ \\
Fertilizer (F) & 1 & $11.02^{\text {ns }}$ & $62.8^{\text {ns }}$ & $1102.08^{* *}$ & $824.19^{* *}$ & $2289.42^{* *}$ & $2401.26^{* *}$ & $245059^{* *}$ & $13530.7^{* *}$ & $1079.2^{* *}$ & $1141.4^{* *}$ \\
V X F & 23 & $7.18^{\text {ns }}$ & $121.9^{\text {ns }}$ & $33.22^{\text {ns }}$ & $6.62^{\text {ns }}$ & $13.14^{* *}$ & $82.09^{* *}$ & $2320^{\text {ns }}$ & $88.9^{\text {ns }}$ & $14.69^{\text {ns }}$ & $19.91^{\text {ns }}$ \\
Residual & 141 & 25.92 & 163.8 & 50.09 & 10.05 & 1.37 & 2.82 & 2473 & 123.6 & 10.08 & 15.19 \\
Total & 191 & & & & & & & & & & \\
\hline
\end{tabular}

NOPG $=$ Number of plants germinated; GP = Germination Percentage; NOPEPP = Number of plants established per plot; NOTPP $=$ Number of tillers per plant; DFF $=$ Days to $50 \%$ flowering; DTM $=$ Days to Maturity; FWOB $=$ Fresh weight of biomass ( $\mathrm{g}, 3$ plants); DWOB $=$ Dry weight of biomass ( $\mathrm{g}, 3$ plants); NOPPP $=$ Number of panicles per plant; GYPP $=$ Grain yield per plant $(\mathrm{g})$.

Table 2. Effect of variety, $\mathrm{P}$ application and their interaction on rice growth parameters

\begin{tabular}{|c|c|c|c|c|c|c|c|c|c|c|}
\hline Variety & NOPG & $G P$ & NOPEPP & NOTPP & $D F F$ & DTM & NOPPP & FWOB & DWOB & GYPP \\
\hline AZUCENA & 9.6 & 32.5 & 29 & 11 & 111 & 136 & 3 & 64.6 & 34.7 & 1.2 \\
\hline CG 14 & 15.5 & 51.7 & 38 & 16 & 72 & 107 & 13 & 177.4 & 58.2 & 5.2 \\
\hline FKR 43 & 12.3 & 40.8 & 34 & 5 & 78 & 111 & 5 & 73.8 & 37.9 & 6.7 \\
\hline IAC 165 & 12.0 & 40.0 & 35 & 5 & 76 & 105 & 5 & 95.7 & 38.5 & 4.3 \\
\hline IDSA 85 & 8.0 & 33.8 & 20 & 8 & 92 & 123 & 7 & 99.8 & 40.2 & 5.0 \\
\hline IR12979-24-1 & 8.3 & 27.9 & 23 & 10 & 96 & 125 & 5 & 80.4 & 41.6 & 2.0 \\
\hline IRAT 216 & 12.8 & 43.2 & 38 & 7 & 87 & 118 & 5 & 79.0 & 36.1 & 0.8 \\
\hline ITA 150 & 12.8 & 42.5 & 33 & 5 & 78 & 116 & 5 & 73.5 & 34.8 & 4.0 \\
\hline ITA 257 & 4.1 & 12.0 & 8 & 3 & 87 & 120 & 4 & 102.6 & 42.2 & 5.8 \\
\hline KASALATH & 5.6 & 18.8 & 14 & 7 & 104 & 135 & 7 & 73.4 & 35.7 & 7.2 \\
\hline MOROBEREKAN & 14.6 & 48.8 & 34 & 5 & 83 & 115 & 0 & 126.6 & 46.0 & 0.0 \\
\hline NERICA 1 & 11.5 & 38.3 & 29 & 7 & 75 & 107 & 6 & 101.5 & 39.0 & 4.7 \\
\hline NERICA 10 & 10.5 & 32.3 & 31 & 6 & 76 & 106 & 6 & 73.7 & 35.6 & 3.8 \\
\hline NERICA 14 & 50.8 & 31.4 & 57 & 7 & 68 & 97 & 6 & 87.6 & 37.9 & 5.4 \\
\hline NERICA 2 & 12.3 & 40.8 & 34 & 5 & 80 & 110 & 4 & 53.9 & 33.9 & 1.8 \\
\hline NERICA 3 & 10.8 & 35.8 & 29 & 5 & 76 & 107 & 4 & 66.3 & 34.6 & 6.7 \\
\hline NERICA 4 & 13.4 & 44.6 & 39 & 5 & 74 & 106 & 5 & 91.4 & 38.0 & 3.9 \\
\hline TOX 1011-4-A2 & 4.9 & 16.3 & 11 & 5 & 88 & 117 & 5 & 100.3 & 40.1 & 10.2 \\
\hline WAB 181-18 & 6.6 & 22.1 & 18 & 5 & 83 & 108 & 5 & 62.2 & 32.8 & 4.2 \\
\hline WAB 56-104 & 8.5 & 27.1 & 25 & 5 & 86 & 116 & 6 & 68.6 & 33.4 & 6.7 \\
\hline WAB 56-125 & 10.4 & 32.9 & 26 & 5 & 78 & 113 & 5 & 100.8 & 41.7 & 3.0 \\
\hline WAB 56-50 & 11.1 & 35.0 & 34 & 7 & 78 & 118 & 4 & 87.9 & 37.4 & 2.4 \\
\hline WAB 96-1-1 & 12.9 & 37.7 & 32 & 9 & 78 & 114 & 5 & 108.8 & 40.6 & 2.9 \\
\hline WAB189BBB8HB & 4.8 & 17.5 & 8 & 4 & 87 & 118 & 4 & 75.8 & 36.3 & 3.7 \\
\hline Lsd & 5.03 & 12.65 & 7 & 3 & 1 & 2 & 3 & 49.15 & 10.99 & 3.85 \\
\hline \multicolumn{11}{|l|}{ Fertilizer } \\
\hline$-\mathbf{P}$ & 11.58 & 32.92 & 25.82 & 4.44 & 86 & 118 & 2.74 & 52.8 & 30.23 & 1.8 \\
\hline$+\mathbf{P}$ & 12.06 & 34.06 & 30.61 & 8.58 & 79 & 111 & 7.48 & 124.3 & 47.02 & 6.67 \\
\hline Lsd & & & 2.02 & 0.91 & 0.33 & 0.47 & 0.91 & 14.19 & 3.17 & 1.11 \\
\hline \multicolumn{11}{|l|}{$\mathbf{P}>\mathbf{F}$} \\
\hline Variety & & & $<0.001$ & $<0.001$ & $<0.001$ & $<0.001$ & $<0.001$ & 0.004 & 0.02 & $<0.001$ \\
\hline Fertilizer & & & $<0.001$ & $<0.001$ & $<0.001$ & $<0.001$ & $<0.001$ & $<0.001$ & $<0.001$ & $<0.001$ \\
\hline Variety $x$ fertilizer. & & & 0.874 & 0.879 & $<0.001$ & $<0.001$ & 0.095 & 0.548 & 0.819 & 0.171 \\
\hline
\end{tabular}


Table 3. Main effects of genotypes and fertilizer on the parameters

\begin{tabular}{|c|c|c|c|c|c|c|c|c|c|c|}
\hline Variety & NOPG & GP & NOPEPP & NOTPP & DFF & DTM & NOPPP & FWOB & DWOB & GYPP \\
\hline AZUCENA & 9.6 & 32.5 & 29 & 11 & 111 & 136 & 3 & 64.6 & 34.7 & 1.2 \\
\hline CG 14 & 15.5 & 51.7 & 38 & 16 & 72 & 107 & 13 & 177.4 & 58.2 & 5.2 \\
\hline FKR 43 & 12.3 & 40.8 & 34 & 5 & 78 & 111 & 5 & 73.8 & 37.9 & 6.7 \\
\hline IAC 165 & 12.0 & 40.0 & 35 & 5 & 76 & 105 & 5 & 95.7 & 38.5 & 4.3 \\
\hline IDSA 85 & 8.0 & 33.8 & 20 & 8 & 92 & 123 & 7 & 99.8 & 40.2 & 5.0 \\
\hline IR12979-24-1 & 8.3 & 27.9 & 23 & 10 & 96 & 125 & 5 & 80.4 & 41.6 & 2.0 \\
\hline IRAT 216 & 12.8 & 43.2 & 38 & 7 & 87 & 118 & 5 & 79.0 & 36.1 & 0.8 \\
\hline ITA 150 & 12.8 & 42.5 & 33 & 5 & 78 & 116 & 5 & 73.5 & 34.8 & 4.0 \\
\hline ITA 257 & 4.1 & 12.0 & 8 & 3 & 87 & 120 & 4 & 102.6 & 42.2 & 5.8 \\
\hline KASALATH & 5.6 & 18.8 & 14 & 7 & 104 & 135 & 7 & 73.4 & 35.7 & 7.2 \\
\hline MOROBEREKAN & 14.6 & 48.8 & 34 & 5 & 83 & 115 & 0 & 126.6 & 46.0 & 0.0 \\
\hline NERICA 1 & 11.5 & 38.3 & 29 & 7 & 75 & 107 & 6 & 101.5 & 39.0 & 4.7 \\
\hline NERICA 10 & 10.5 & 32.3 & 31 & 6 & 76 & 106 & 6 & 73.7 & 35.6 & 3.8 \\
\hline NERICA 14 & 50.8 & 31.4 & 57 & 7 & 68 & 97 & 6 & 87.6 & 37.9 & 5.4 \\
\hline NERICA 2 & 12.3 & 40.8 & 34 & 5 & 80 & 110 & 4 & 53.9 & 33.9 & 1.8 \\
\hline NERICA 3 & 10.8 & 35.8 & 29 & 5 & 76 & 107 & 4 & 66.3 & 34.6 & 6.7 \\
\hline NERICA 4 & 13.4 & 44.6 & 39 & 5 & 74 & 106 & 5 & 91.4 & 38.0 & 3.9 \\
\hline TOX 1011-4-A2 & 4.9 & 16.3 & 11 & 5 & 88 & 117 & 5 & 100.3 & 40.1 & 10.2 \\
\hline WAB 181-18 & 6.6 & 22.1 & 18 & 5 & 83 & 108 & 5 & 62.2 & 32.8 & 4.2 \\
\hline WAB 56-104 & 8.5 & 27.1 & 25 & 5 & 86 & 116 & 6 & 68.6 & 33.4 & 6.7 \\
\hline WAB 56-125 & 10.4 & 32.9 & 26 & 5 & 78 & 113 & 5 & 100.8 & 41.7 & 3.0 \\
\hline WAB 56-50 & 11.1 & 35.0 & 34 & 7 & 78 & 118 & 4 & 87.9 & 37.4 & 2.4 \\
\hline WAB 96-1-1 & 12.9 & 37.7 & 32 & 9 & 78 & 114 & 5 & 108.8 & 40.6 & 2.9 \\
\hline WАВ189BВB8НB & 4.8 & 17.5 & 8 & 4 & 87 & 118 & 4 & 75.8 & 36.3 & 3.7 \\
\hline Lsd & 5.03 & 12.65 & 7 & 3 & 1 & 2 & 3 & 49.15 & 10.99 & 3.85 \\
\hline Fertilizer & ns & $\mathrm{ns}$ & & & & & & & & \\
\hline$-\mathbf{P}$ & 11.58 & 32.92 & 25.82 & 4.44 & 86.375 & 117.92 & 2.74 & 52.8 & 30.23 & 1.8 \\
\hline$+\mathbf{P}$ & 12.06 & 34.06 & 30.61 & 8.58 & 79.469 & 110.84 & 7.48 & 124.3 & 47.02 & 6.67 \\
\hline
\end{tabular}

Table 4. Crop establishment and phenological responses to interactive effects of genotype and phosphorus treatment

\begin{tabular}{lcccccccccc}
\hline & \multicolumn{2}{c}{ NOPG } & \multicolumn{2}{c}{ GP } & \multicolumn{2}{c}{ NOPEPP } & \multicolumn{2}{c}{ NOTPP } & \multicolumn{2}{c}{ DFF } \\
\hline Variety & NP & P & NP & P & NP & P & NP & P & NP & P \\
AZUCENA & 9.0 & 10.3 & 30.0 & 35.0 & 32 & 26 & 9 & 14 & 111 & 111 \\
CG 14 & 14.0 & 17.0 & 46.7 & 56.7 & 40 & 37 & 13 & 19 & 75 & 69 \\
FKR 43 & 13.0 & 11.5 & 43.3 & 38.3 & 39 & 30 & 3 & 7 & 83 & 73 \\
IAC 165 & 12.0 & 12.0 & 40.0 & 40.0 & 35 & 35 & 4 & 7 & 81 & 71 \\
IDSA 85 & 7.3 & 8.8 & 24.2 & 43.3 & 20 & 20 & 5 & 11 & 95 & 90 \\
IR12979-24-1 & 7.8 & 8.8 & 25.8 & 30.0 & 26 & 19 & 8 & 13 & 100 & 92 \\
IRAT 216 & 11.3 & 14.3 & 37.5 & 49.0 & 42 & 34 & 5 & 9 & 90 & 84 \\
ITA 150 & 13.0 & 12.5 & 43.3 & 41.7 & 35 & 31 & 3 & 7 & 83 & 74 \\
ITA 257 & 3.0 & 5.3 & 10.0 & 14.0 & 9 & 7 & 3 & 3 & 93 & 82 \\
KASALATH & 4.3 & 7.0 & 14.2 & 23.3 & 16 & 12 & 4 & 11 & 108 & 100 \\
MOROBEREKAN & 16.3 & 13.0 & 54.2 & 43.3 & 32 & 37 & 3 & 7 & 86 & 80 \\
NERICA 1 & 10.3 & 12.8 & 34.2 & 42.5 & 34 & 24 & 5 & 9 & 78 & 72 \\
NERICA 10 & 11.8 & 9.3 & 39.2 & 25.5 & 33 & 29 & 4 & 8 & 80 & 72 \\
NERICA 14 & 51.3 & 50.3 & 34.2 & 28.7 & 59 & 55 & 5 & 9 & 71 \\
NERICA 2 & 12.3 & 12.3 & 40.8 & 40.8 & 35 & 34 & 3 & 6 & 85 \\
NERICA 3 & 12.0 & 9.5 & 40.0 & 31.7 & 32 & 25 & 3 & 7 & 79 \\
NERICA 4 & 12.0 & 14.8 & 40.0 & 49.2 & 44 & 34 & 5 & 6 & 77 \\
TOX 1011-4-A2 & 5.3 & 4.5 & 17.5 & 15.0 & 11 & 10 & 2 & 8 & 92 \\
WAB 181-18 & 7.0 & 6.3 & 23.3 & 20.8 & 20 & 16 & 3 & 6 & 85 \\
WAB 56-104 & 8.8 & 8.3 & 29.2 & 25.0 & 26 & 24 & 3 & 7 & 85 \\
\hline
\end{tabular}




\begin{tabular}{lcccccccccc}
\hline WAB 56-125 & 9.0 & 11.8 & 30.0 & 35.8 & 30 & 22 & 4 & 6 & 80 & 75 \\
WAB 56-50 & 10.5 & 11.8 & 35.0 & 35.0 & 39 & 28 & 4 & 9 & 82 & 75 \\
WAB 96-1-1 & 12.3 & 13.5 & 40.8 & 34.5 & 38 & 26 & 4 & 13 & 80 & 76 \\
WAB189BBB8HB & 5.0 & 4.5 & 16.7 & 18.3 & 10 & 7 & 2 & 5 & 91 & 84 \\
\hline Lsd (0.05) & \multicolumn{2}{c}{ NS NS } & NS & NS & & $\mathbf{2}$ \\
\hline
\end{tabular}

Table 5. Maturity and yield component responses to the interactive effects of genotype and phosphorus

\begin{tabular}{|c|c|c|c|c|c|c|c|c|c|c|}
\hline \multirow[b]{2}{*}{ Variety } & \multicolumn{2}{|c|}{ DTM } & \multicolumn{2}{|c|}{ NOPPP } & \multicolumn{2}{|c|}{ FWOB } & \multicolumn{2}{|c|}{ DWOB } & \multicolumn{2}{|c|}{ GYPP } \\
\hline & NP & $\mathbf{P}$ & $\mathbf{N P}$ & $\mathbf{P}$ & $\mathbf{N P}$ & $\mathbf{P}$ & $\mathbf{N P}$ & $\mathbf{P}$ & NP & $\mathbf{P}$ \\
\hline AZUCENA & 142 & 131 & 0 & 7 & 37 & 92.2 & 26.67 & 42.8 & 0 & 2.43 \\
\hline CG 14 & 112 & 102 & 7 & 20 & 82.3 & 272.5 & 38.9 & 77.52 & 1.08 & 9.34 \\
\hline FKR 43 & 115 & 108 & 3 & 7 & 50.1 & 97.4 & 29.6 & 46.15 & 2.94 & 10.55 \\
\hline IAC 165 & 114 & 96 & 2 & 7 & 61.5 & 129.8 & 30.02 & 46.97 & 0.67 & 7.92 \\
\hline IDSA 85 & 126 & 121 & 5 & 9 & 67 & 132.6 & 35.52 & 44.92 & 1.75 & 8.25 \\
\hline $\begin{array}{l}\text { IR12979-24- } \\
1\end{array}$ & \multicolumn{10}{|c|}{1} \\
\hline IRAT 216 & 120 & 115 & 2 & 8 & 44.5 & 113.5 & 28.15 & 44 & 0.1 & 1.49 \\
\hline ITA 150 & 120 & 111 & 2 & 7 & 55.4 & 91.6 & 30.9 & 38.72 & 1.63 & 6.42 \\
\hline ITA 257 & 124 & 116 & 3 & 4 & 66.7 & 138.6 & 33.62 & 50.67 & 5.81 & 5.78 \\
\hline KASALATH & 139 & 130 & 2 & 13 & 37.7 & 109.1 & 27.27 & 44.2 & 0.18 & 14.22 \\
\hline MOROBER & 118 & 111 & 0 & 0 & 88.5 & 164.8 & 36 & 55.9 & 0 & 0 \\
\hline \multicolumn{11}{|l|}{ EKAN } \\
\hline NERICA 1 & 112 & 103 & 3 & 8 & 47.6 & 155.3 & 28.57 & 49.42 & 1.8 & 7.56 \\
\hline NERICA 10 & 111 & 101 & 4 & 8 & 35.9 & 111.4 & 27.42 & 43.67 & 1.62 & 6.01 \\
\hline NERICA 14 & 102 & 91 & 4 & 9 & 55.1 & 120.1 & 32.05 & 43.8 & 2.21 & 8.48 \\
\hline NERICA 2 & 114 & 106 & 3 & 5 & 42.7 & 65.1 & 28.27 & 39.45 & 0.51 & 3.12 \\
\hline NERICA 3 & 111 & 102 & 2 & 6 & 57.4 & 75.1 & 29.72 & 39.4 & 6.29 & 7.13 \\
\hline NERICA 4 & 110 & 102 & 3 & 6 & 58.9 & 123.8 & 31.05 & 44.85 & 1.43 & 6.32 \\
\hline TOX & 124 & 111 & 2 & 7 & 64.6 & 136.1 & 31.6 & 48.5 & 6.59 & 13.86 \\
\hline \multicolumn{11}{|l|}{ 1011-4-A2 } \\
\hline WAB 181-18 & 104 & 112 & 2 & 8 & 45.1 & 79.4 & 27.95 & 37.58 & 0.78 & 7.56 \\
\hline WAB 56-104 & 124 & 108 & 3 & 9 & 39.3 & 97.8 & 27.2 & 39.55 & 2.76 & 10.54 \\
\hline WAB 56-125 & 110 & 115 & 3 & 6 & 55 & 146.7 & 30.77 & 52.62 & 1.49 & 4.5 \\
\hline WAB 56-50 & 115 & 120 & 2 & 6 & 46.6 & 129.1 & 28.25 & 46.6 & 0.23 & 4.58 \\
\hline WAB 96-1-1 & 113 & 116 & 3 & 8 & 58.4 & 159.2 & 31.25 & 49.9 & 0.91 & 4.93 \\
\hline \multicolumn{11}{|l|}{ B8HB } \\
\hline Lsd & & & & & & & & & & \\
\hline
\end{tabular}

\section{Discussion}

The significant effect recorded with addition of $\mathrm{P}$ fertilizer on number of tillers per plant, days to maturity, dry weight of biomass and grain yield showed that $\mathrm{P}$ fertilizer is very critical in rice production in the northern region of Ghana. This result is consistent with findings by other research in the region that suggest that $\mathrm{P}$ is second most limiting nutrient in soils in the Guinea Savanna agro-ecological zone of the region. More so, there results further stressed the importance of $\mathrm{P}$ in rice cultivation. Varieties that received $\mathrm{P}$ fertilizer resulted in higher and significant grain yield as a result of improved photosynthetic activity leading to higher tillering by the rice crop. Furthermore, phosphorus is also a component of other compounds necessary for protein synthesis and transfer of genetic material DNA, RNA (Wilson et al., 2006).

Additionally, results of this experiment showed increased grain yield by varieties which was significantly different from varieties that received no $\mathrm{P}$ because water availability was controlled to avoid flooding. Other studies have showed that phosphorus application to rice increased $\mathrm{P}$ accumulation but did not consistently increase rice yields because flooding which decreased soil $\mathrm{P}$ sorption and increased $\mathrm{P}$ diffusion. It is however clear from the results of this experiment that, addition of $\mathrm{P}$ to upland rice will not only improve $\mathrm{P}$ accumulation but will increase grain yield significantly. The higher tolerance of ITA 257, Nerica 3 and TOX 1011-4-A2 
varieties to low $\mathrm{P}$ application could be attributed to higher $\mathrm{P}$ use efficiency.

\section{Summary and Conclusion}

Rice growth and yield parameters were affected by Phosphorus application. Plants that received phosphorus flowered and matured earlier. They also accumulated higher biomass and grain yield. ITA 257, Nerica 3 and TOX 1011-4-A2 were tolerant to P deficiency. There was no variety x P interaction, however.

\subsection{Recommendation}

Further screening is needed to select varieties that are tolerant to $\mathrm{P}$ deficiency and well adapted to the agro-ecological zone.

\section{Acknowledgements}

We would like to show our gratitude to Japan International Research Center for Agricultural Sciences (JIRCAS) for giving us financial support to carry out this experiment. We would also like to expand our deepest gratitude to management and staff of CSIR-Savanna Agricultural Research Institute, especially the Director, for giving us the opportunity to undertake this study at the institute's experimental field.

\section{Reference}

De Datta, S. K. (1965). Phosphate availability and fertilizer Res. Inst. Thursday Seminar 2 September 1965 Loss Banos- Philippines.

De Datta, S. K. (1981). Principles and practices office production (p. 618). New York: John Wiley and sons.

Fox, R. L., \& Kamprath, E. J. (1970). Phosporus sorption isothems for evaluating the phosphorus requirement of soils. Soil Sci. Soc. Am, Proc., 34, 902-907.

Fox, R. L., \& Searley, P. G. (1978). Phosporus sorption by the soils of the tropics ASA Spec. Publ. 34Medison Wisconsin (pp. 97-117).

Koyama, T., \& Chammek, C. (1971). Soil plant nutrition studies on tropical rice. Studies on varietal differences in soil low in available phosphorus. Soli Sel. Plant Nutr., ll(3), 115-126.

Koyama, T., \& Chammek, C. (1971a). Soil plant nutrition studies on tropical rice. Studies on varietal differences in absorbing phosphorus. Soil Sci. Plant. Nutr., 17(3), 186-194.

Tadano, T., \& Tanaka, A. (1980). Comparison of tolerance to low phosphorus supply among crop plants (part 1). Response to low phosphate concentration in culture solution during early growth stages. Studies of the comparative plant nutrition (Abstr.). J. Sei. Soil and Manure (Japan), 51(5), 349-404.

\section{Copyrights}

Copyright for this article is retained by the author(s), with first publication rights granted to the journal.

This is an open-access article distributed under the terms and conditions of the Creative Commons Attribution license (http://creativecommons.org/licenses/by/3.0/). 